УДК 821.163.41-1.09 Тешић М.

https://doi.org/10.18485/godisnjak.2021.16.11

Ана Б. Гвозденовић

Народна библиотека „Стефан Првовенчани”

Краљево
Оригинални научни рад

Примљен: 23. 09. 2021.

Прихваћен: 05. 11. 2021.

\title{
ЛИРСКИ ЦИКЛУСИ У КЮИЗИ МИЛОСАВА ТЕШИЋА ПРИВИД КРУГА
}

У раду се, на примеру књиге Привид круга, разматра одраније у књижевној критици уочена склоност Милосава Тешића да своје поетско ткање организује у шире лирске или лирско-епске целине (кругове, циклусе, поеме). Полазећи првенствено од теоријских закључака Елени Апостолос Стерјопулу, аутор настоји да покаже каки разноврсна интертекстуална лексичка понављања (од најједноствнијих на нивоу појединачних лексема до оних најсложенијих која заправо представљају дозивање карактеристичног асоцијативног низа својственог одређеном културном кругу или поетици аутора) омогућавају Тешићу да Привид круга структурира као ииклус ииклуса али и да значења ове књиге доведе у тесну везу са својим ранијим опусом градећи препознатљиву поетско-митолошку творевину. Ова чврсто компонована песничка грађевина свој пуни смисао добија уз читање песникових коментара и у дослуху са његовим ранијим књигама.

Кључне речи: лирски циклус, поема, коментар, културно наслеђе, сећање.

Књига Милосава Тешића Привид круга на препознатљив и особен лирски начин пева о нашем постојању, историјском и судбинском удесу - од прастарих времена до данас (тај хронолошки след јасно се прати од уводних до завршних стихова, а иако би се условно могло рећи да се у

*gvozdenaana@gmail.com 
њега укључени наша средњовековна историја, преко периода турске владавине, до новијих времена, страдања у Првом светском рату и актуелног тренутка, хришћански и митолошки аспекти у овај оквир дозивају и много старије слојеве). ${ }^{1}$ Већина песама је организована у циклусе ${ }^{2}$, формално и тематски повезане целине, док посебан статус имају пролошка песма „Некропола у Дићима селу” и такође самостално издвојена дужа песма „Плава гробница - Видо”. Књигу завршава „Глосар”, који је њен саставни део, управо као што су „Коментари” неодвојиви од „Итаке”. 3

Уводна песма „Некропола у Дићима селу” у себи већ сједињује две односно три поменуте хронолошке али и значењске равни. На једној страни су описи материјалних остатака цркве и некрополе вероватно с почетка 14. века а на другој „хук с магистрале” (Ибарске, потез Љиг Горњи Милановац) и тренутак из кога се јавља глас лирског субјекта. Ова два тренутка, као и векове који стоје између њих, надилази виша, метафизичка стварност, симболички представљена сликом тајанственог ткача, као и анђела који свира у космичке гајде. Запитаност над значењем симбола урезаних на надгробним плочама од кварцног пешчара:

${ }^{1}$ „Гледано и уметнички и неуметнички, чврсто сам везан, везан до нераскидивости, за родно тле, за народ којем припадам, за његов језик и историју и за свеукупно наше културно наслеђе." (Тешић 2003: 203)

2 У одређењу циклуса, држаћемо се дефиниције Елени Апостолос Стерјопулу: „Лирским циклусом називамо заједничким насловом обједињено уређено мноштво самосталних песничких текстова који реализују интертекстуалне везе различитог нивоа, које стварају нове смисаоне комплексе неизводљиве из смисаоног система било ког појединачног текста." (Стерјопулу 2003, 124-125)

3 ,Улога напомена и разјашњења се не исцрпљује указивањем на коришћене податке него они битно утичу на читање и разумевање песме. Песник њима открива, и хотимице и нехотице, делове своје песничке радионице и иманентне поетике. Читалац није више само пуки трагалац за податком, на шта се понекад сводио његов улог: откривање података му је, могуће, давало илузију да разуме песнички текст. Ослобођен притиска ванкњижевног знања (Препознати - зар на то да се своди сврха? - како би рекао Иван В. Лалић), он постаје опремљени тумач смисла, усредсређен на песнички поступак и удео подтекста у тексту, на 'пуније значење' конкретних стихова и целе поеме. Због тога су сви коментари постали саставни део песничких збирки и поема на које се односе и неопходно их је убудуће увек штампати заједно." (Јовановић 2018: 98-99)

Осим тога што ауторске напомене омогућавају да се у време, како песник у више наврата наглашава, јаке англизације савременог српског језика и поплаве информатичке и медијске лексике, његово дело боље разуме на лексичком плану, Милосав Тешић верује да те назнаке и разјашњена обогаћуjу његове књиге, чинећи их „садржајно ширим, значењски пунијим и утемељенијим, некако временски обухватнијим и дужим, естетички пространијим...” (Тешић 2017: 496, подвукла А. Г.) 
Шта цртежом значе под смрти котачем: круг, крстови, црте, те израз-розете и шкрте фигуре - апстракције с мачем?

води до спознања Ума од кога узмичу мрак и грдила, пред којим се повлачи ништина.

Како у „Глосару” читамо, све три песме циклуса који следи, „Кад уклони застор најтамнија сенка", у ствари су допеви за поему Калопера Пера, написани после њеног објављивања 2018. године. ${ }^{4}$

У „Глосару уз поему Клопера Пера” у „Уводним напоменама” аутор је забележио:

„У поеми Калопера Пера (коју чини 285 стихова, испеваних у амфибрашком дванаестерцу) првенствено се опевају и славе - на инспиративној подлози коју чини митски свет вила у српској народној уобразиљи - знане и незнане српске хероине. У њих се рачунају и жене других националности и вера које су у неком историјском тренутку, вођене својом племенитошћу, добровољно притекле у помоћ српском народу када се нашао у некој од својих бројних недаћа - помажући му несебично и пожртвовано.” (Тешић 2018: 31)

Да је реч о чврсто изграђеној структури, потврђују и речи аутора о месту које новонастали делови заузимају у већ постојећој творевини: „То значи да она (поема Калопера Пера) сада има 20 уместо досадашњих 17 целина, међу којима првој песми припада XIV позиција, другој XV, a трећој XVIII."

У контексту књиге Привид круга оне чине тематски издвојену целину у чијем се средишту налази интересовање за судбину жене, оне која је остала записана у историји, као и оне непознате, чије је име тек траг из прошлих времена. Ипак, због свога дела, оне су, и једне и друге, трепетьике „у кретању боја”, трепке, светла која исијавају из далеке прошлости. Све три песме су слично компоноване: након уводне, условно митолошке строфе, у којој срећемо виле и чудновати свет биља, следи конкретизација у строфама посвећеним реалним, историјским личностима. Тако се у првој песми овог циклуса, „Да испуни реч се и заветно слово”, након осврта на виле, бритке видарке, које своје мелеме налазе у свету лековитог и хранљивог биља (коренак, здравац, коприва, споришак, козлац, коприва, слез, гавез, боквица...) крај воде (потока, зденца, речице, локве), песник окреће Делфи Иванић, хуманитарној и просветној радници, са чијом нас

\footnotetext{
${ }^{4}$ Први пут поема је објављена 2006. у Београдском књижевном часопису (3/2006) а потом као самостални уводни циклус у збирци Дар и коб (Београд: Чигоја штампа, 2006). Тада је имала 172 стиха али ју је аутор, како видимо, више пута проширивао.

${ }^{5}$ Оно што лирски циклус разликује од поеме јесте одсуство чврстог сижејног оквира.
} 
судбином ближе упознаје у „Глосару”, и Милунки Савић, храброј хероини, о којој белешку у „Глосару” прати и бритки закључак: „Сахрањена је на Новом гробљу у Београду, којом приликом су, мада најављене, изостале све државне и војне почасти.” (Овакви критички коментари и отворени обрачун са друштвом које уместо памћења промовише заборав преплавиће завршни циклус књиге.) Следећа песма у овоме низу, „Евлин”, такође има митолошки увод посвећен вили са Повлена и тематизацији искона и почела, након кога следи лирска повест Евлин Хаверфилд, која је као чланица Болница шкотских сестара у току Првог светског рата дошла у Србију и била добровољна болничарка, а по завршетку рата о свом трошку отворила и издржавала Дом за ратну сирочад и болесну децу у Бајиној Башти. Отуда је ова сиротињска мајка атрибутима доведена у везу са у уводу поменутом вилом: златокоса Евлин, та Змај-Евелина!... Баш као што су предањске виле успевале да задоје нејач и закриле благо тако и жене-хероине с почетка XX века (а Евлин је једна од њих) успевају да нахране изгладнелу, бледу и свелу дечицу, проносећи једнако дух племените сорте и указујући на безмерну милост Оца и обећање Васкрсења. Посебну пажњу залужује песма по којој је и насловљен овај кратак циклус - „Кад уклони застор најтамнија сенка”. Након тамног и злослутног увода у коме читамо о времену у коме је миље ишчезло из живота а ништани зјапе, виле цвиле а извори из уводне строфе претходне песме су пресахли, следи низ од симболичних 33 имена која „означавају оне девојчице или сасвим младе девојке које је зла судбина, било које врсте, спречила да остваре неки од својих посебних дарова” („Глосар”, стр. 96-97). Готово сва ова имена узета су из Рачанског поменика, у који су их рачански монаси уписали углавном у периоду између 1616. и 1682 . године. Управо је њихово нематеријално постојање доказ постојања вишега реда и смисла јер су оне трепетљике, честице, трепке које исијавају светлост и дају смисао нашем овоземаљском постојању:

трепетљике то су у кретању боја кад уклони застор најтамнија сенка и започну прсти тајанствених сила да танано раде по смислу од смиља.

Односно:

избијају оне кроз значења двојна, што љуто се косе - и бела и црна. Те честице, трепке, те чар-љубичице, кад разведри тма се у Час распрснућа 
и раздреши Чвор се, тренутке у свице преобразе оне! - Тај трен напрегнућа учинио то је да с Небеског свитка зрак расточи жито по Чаши небитка.

Ова песма свој „мушки” пандан налази у песми „Плава гробница Видо", у којој читамо опет својеврсни попис, поменик овога пута мушких имена, и то оних који су свој овоземаљски пут завршили у Плавој гробници. Као што се у уводу „женског” поменика наглашава мотив сећања које покрива тама заборава (То иявиљење ток је у Свет ишчезнућа / mе сећање свако у тмуиу зарасте), тако и овде срећемо памћење које бива све тање и тање, а у обе ове песме јасно је наглашено супротстављање мрака и ништавила, у које води заборав, и светлости, која зрачи (трепетљике, мошти) из прошлости. Управо чување имена представља својеврсно чување сећања и осмишљава наше постојање укључујући га у низ који се завршава Васкрсењем тј. Откровењем. Раније поменутом хуку са магистрале (из уводне песме „Некропола у Дићима селу”) овде одговара бука „флотила што журе, сирене што трубе”, глисер-комете, бука живота у трку насупрот којој је мук-осећање, што је миром надилази. Јеванђељска јава тако се указује као вишње постојање којим се превазилазе „значења општа од пене и праха". Пена и прах у асоцијативном низу лако дозивају привид из наслова збирке. Како је професор Радивоје Микић на то указао: „Тако се у Тешићевој песми окончава кретање од историје и емпирије ка сфери неземаљског, у најширем смислу метафизичког” (Микић, 2020: 19). ${ }^{6}$ Ове две читуље шире од летьега дана, мушка и женска, која сем поменутих имена дозивају и многа друга (У Тачкама Трима имена су ина...) постају тако штит у борби против бесмисла и одговор на заборав који лирско ја боли више од зле судбине страдалника. Песма је тако „евокативно средство, чувар онога што тоне у таму времена и зато је она означена као “лековита биљка", (Микић 2020: 17).

${ }^{6}$ Као метафизичког песника Милосава Тешића одређује, на пример, и Никша Стипчевић: „Хоће (М. Т.) да нам каже - све пропада, само језик остаје, језиком се може оживети камење. In litteris - memoria. Од пролазности, од пропадања, језик спасава. У језику је трајање, а не у зиду, у камену, у здању." (Стипчевић 1998: 22)

${ }^{7}$ Слично запажање, поводом поеме Калопера Пера, изнео је Александар Јовановић, који примећује да све у овој поеми, од њених првих до завршних стихова, „води ка песничком и културном памћењу”: ,зато је Калопера Пера, упоредо са снажним евокативним тоном, цела прожета тихом радошћу због моћи поезије да увек изнова наставља нит између прошлог и савременог, без које би опустело и оно што је било и оно што ће тек да буде.” (Јовановић 2018: 104)

Ова мисао присутна је у поезији Милосава Тешића одраније, па тако Љубомир Симовић, пишући о књизи Прелест севара, Круг рачански, Дунавом (1996), истиче песникову заокупљеност функцијом језика да све чува и памти. (Симовић 1998: 26) 
У следећи циклус, „Разгледнице са Смиљевог поља”, уводе нас два мотоа: један је цитат из Глишићеве приповетке „После деведесет година" (1880) посвећен опису воденице ${ }^{8}$ а други (Све су смрти откинуте капи) је потписан као исказ сељанке која разговара са неким у аутобусу „који се пењао ваљевским путем из Рогачице на Дебело брдо”. Мото је важан циклотворни елемент који путем асоцијација из изворног текста у нови преноси одређени круг осећања и идеја. Наведени „цитати” јасно истичу две равни: фолклорну и реалистичку на чијим преплитањима су изграђени стихови који следе али и централна тема ове целине - смрт и њено метафизичко осмишљење.

Циклус чини девет песама, изграђених од по седам дистиха. Не само да су песме унутар циклуса повезане врстом одабраног стиха, дакле формално, и тематско-мотивски, већ се и песме из различитих циклуса повезују и дозивају понављањем истих или сличних речи и варирањем истих мотивских склопова. Ова повезивања надилазе циклусне целине и обухватају читаву збирку, а нека од њих су карактеристична за Тешићево стваралаштво у целини. Тако су и у овом цикулусу, који условно тематизује питања коначнога смисла те односа материјалног и нематеријалног, твари и Нетвари, светлости и таме, односно Божјег стварања, појединачне песме не само међу собом повезане већ успостављају значењске односе и са онима које претходе односно следе овој целини. Када је реч о повезивању унутар самога циклуса, смисао постојања се у његовим песмама одгонета кроз слике смењивања светлости и таме, дана и ноћи, сунца и месеца, односно супротстављања Творца и Светлозориа зјалима која зјапе (зинула) из мрака. Равнотежа ових сила (у крајњој инстанци стваралачке и рушилачке) је нестабилна (О танком су кониу теразије смисла /.../ Сви светови раде на небеска витла, а остаје тајна, нерешива - битна, „Теразије смисла") али и неупитна (Над вечерњим овсом под зведаним бдењем / једначинутвори лепота са мрењем, „У чар нејасноћи”). Њихове представе су вишеструко вариране ширећи спектар својих значења и на опозицију историјског времена и више стварности која га надилази али и на домен језика и језичког стварања и памћења. Једном кругу симбола припадају следеће речи и склопови: сунце, жарити, жутити, заранак, подне што злати, звезде, бело, јечмено злато, ласте, јаребице, овца (јагње), певање ливаде а другом: мрак (мрачити), змија, леденице смрти, тугине влати, месец, грак врана, белоглави суп, сумрак, мрак-маказе, тмуша, црно, гавран, шарка,

\footnotetext{
${ }^{8}$ Воденици поточари - млину, као елементу наше нестале прошлости, посвећена је Тешићева збирка Млинско колу, у којој се терминима везаним за рад воденице могу приписати и значења везана за рад у језику. Видети: Тешић 2017: 498-499.
} 
смук, аждаја, поноћ, гашење боја, тамне скулптуре, празнине, голети, ћутања, језота... Питање Смисла је, и на трагу библијског учења, повезано са питањем језика а стварање са Словом: Обасја ли твари у свој нејасноћи, / енергија Божја у Слову заноћи односно Обневиди придев и створи планету („Над светлим јасиком”). Слично као код Кодера, на пример, и у овом Тешићевом циклусу читамо: Суноврати зрак се са мрамора јаве / $и$ затвори језик у лелује траве („Интеграл од смисла”) а у слике природе, твари и нетвари, уведени су реч, тишина, реченица, Речник мучања, слик, придеви, трусни глаголи, поетички фактори, словно трење (Колико се словног истрошило трења / да створи се облак у Клас Вазнесења, „Под језом открића"), једнице ритма, звук, али и ћутање и нејезик.

Као што је са претходним циклусом повезана помињањем митолошког света вила и биља али можда и значајније смисаоним контекстом истоветних или варираних речи речи трепетљике, трен односно трепет трен, трепере (у значењу најпре епифанијске спознаје, зрнца разума, светлости која продужује трајање али и доноси разјашњење), те Чвор односно чворје (смисла који треба докучити), ${ }^{9}$ тако ова целина стоји у тесној вези са ониме што у збирци следи. Песма „Кроз недатост дату”, на пример, мотивски најављује потоњи циклус „Елегија о пустим кућиштима” а у борби супротстављених светова, макар привремено, однеће силе мрака. Овај циклус започиње цитатом из Књиге пророка Исаије (И тада ће свако мјесто гдје има тисућа чокота за тисућу сребрника зарасти у чкаљ и трюе. Са стријелама и с луком ићи ће се онамо, јер ће сва земља бити чкаљ и трње. VII, 23-24) и стиховима из песме „Запуштени источник” Војислава Илића а чини га 13 песама означених римским бројевима (IXIII; сваку песму сачињава једна строфа од по 10 стихова а појављивање редног броја који означава место песме у циклусу уместо њеног наслова знак је тешњег повезивања целине). Већ у првој песми наилазимо на слику бурјана, чкаља и бујади који се утркују, слику трњака и корова, а тамо где нема људи (Крај школе стоји учитељ без ђака, I), очас завладају представници хтонског (Зелембаћ, лептир - змијарником гујад, I). Опустела кућишта слика су распада родних твари а призор грабљивог кљуна који се баца на чуваркућу уводи нас у свет пропадања, црвоточишта, трулине и мемљивог мириса дуње. Тим светом одзвањају ћуков ћукутак и таман

\footnotetext{
${ }^{9}$ Таквих је примера још, на пример Смиљево поље које се овде нашло у наслову циклуса помиње се у уводном делу песме „Кад уклони застор најтамнија сенка”, која је дала наслов претходној песничкој целини.
} 
тенор луње, а вештица у њему изводи фигуру метле. ${ }^{10}$ Крушка (поменута у мотоу циклуса) од воћке сунца постала је сабласна (Сабласт-крушка), љутите осе насрћу док самотник стараи чува душну овиу (V, овде се треба сетити поменуте слике овце чији трбух пара белоглави супа из ранијег циклуса) а остаци смисла зебу од трезноће (V). Из тмуше, строва и шашља, тек избије снебивљив просјај љупких добричица (VI) а гробља (коров-гроб) казују о прошлом свету (Тек Земљорадња, богиња и мати, / по гробљима се казује да беше, VII). Рађање детета у таквом окружењу наговештено је јаукањем јаук-траве а „хаотично стање постојећег света” представљено је кованицом коров-строј. Целовит мрак је спреман да по Земљи пусти силу црних чета а у таквом отуђеном и опустошеном свету није остао поштеђен ни језик. Тако у овом циклусу наилазимо на Реч људождер, за коју у „Глосару” читамо да је „ознака насилничког, освајачког речника у данашњем глобалистичком устројству обезљуђеног света” (108). Стара змија (ђаво, сотона) све дроби и растаче а мотив трептаја (овога пута малаксавог) и овде је доведен у везу са некадашњим сјајем.

Циклус „У слици и речи” најексплицитније је окренут данашњем тренутку а у њега нас уводе и овога пута два мотоа: цитат из Прича Соломунових о роду који мисли да је чист а од свога кала није опран, „којему су зуби мачеви и кутњаци ножеви, да прождире сиромахе са земље и убоге између људи” и стихови из песме „Позив” Милана Ракића. Отворено критички проговарајући о данашњем свету у коме је живот истовар робе („Аксиом и бином”) а Пирова победа коју меркантилистички дух односи над уметношћу и питањима духа (Пред тријумфом општим финансијских чуда / шта приче и драме, шта лирика худа!, „Аксиом и бином”; Шта уопште значе музеји, палате?, „Док издише правда”; или помињање квара лепоте односно отрова који је уливен у тело културе) води нас још једном до питања коначног смисла у свету у коме $u$ звезде постоје да звече ситнином. Библијски мотив овце још једном је вариран и у овом циклусу, само су сада све овчице листом ухваћене у маказама божанства профита. Опомињу нас стихови Милосава Тешића да лажи премрежују истину те да Силни укидају сва памђења редом и сва осећања. Питање језика и овде је тематизовано јер је његово свођење на суфиксе директно повезано са проблемима опстанка културе и очувања идентитета. У свету сазданом на дихотомији две власти: Звери (Сотона, Аждаја, Диспечер смрти, Анти-

${ }^{10}$ У „Глосару” песник напомиње да је реч о биљци коју карактерише гранат жбун на крошњама шљива или трешања, развијен из пупољака заражених паразитским гљивицама вештичја метла, из чега се још једном чита о превласти дивљег и коровског (па онда и неконтролисаног, хтонског) над оним што је култивисано и оплемењено. 
христ, Ђаво, Вајач опсена, Злотвор, Седмоглава напаст с милион рогова, Злодух, разградитељ душа...) и Духа из Почела, данас су вредности, па и сама значења, изокренути и у своју супротност извргнути (y плусу је минус, живу истину премрежују лажи, Све руши и брише безакоња закон, бешчашћа су канон, злочинции су свеци, убице хероји, или ито јест - не постоји, што вреди - не вреди). Важну улогу у том первертирању истине играју медији и друштвене мреже који потпомажу систем контроле и надзирања у глобалистичком тору.

Иако је насловна синтагма привид круга узета из стихова песме „Плава гробница - Видо”: Животу у трку разрадио квар се / у ритмичкој кретьи по привиду круга, у овоме циклусу можда смо најближи њеном разрешењу. ${ }^{11}$ Наиме, када у песми „Да заплаче честит, / Безазлен да цвили” прочитамо како лирски субјект описујући садашњи, по бројним натукницама у стиховима и коментарима у „Глосару”, апокалиптични тренутак каже: До привида привид - у пени и вуни, онда постаје јасно да се у мору безличности оно сушто затурило а животни млив (круг, млин, точак, жрвањ...) меље до нуле (уништења). Лажни, патворени свет потиснуо је онај Искон и Почело о којима се више певало у уводним циклусима а који су сада тек назначени као нешто нестало. Док се у уводној песми, „Некропола у Дићима селу”, налази слика Круг-озарења, од кога стукну грдила и респлете се мрак, сада Славуји ништине, кроз светлосну тмииу, / литургији живој сасеиају жииу („Што јест - не постоји, што вреди / не вреди).

Привид срећемо и у завршном циклусу књиге, „Са Авале поглед”, који следи после издвојене песме „Плава гробница - Видо”, о којој је већ било речи, а који чини седам песама $(4+4+2)$, означених римским бројевима. У другој песми овога циклуса привид је у новоствореној полусложеници спојен са речју слобода па се тако у овим стихови семантички конктекст уведен у претходном циклусу додатно продубљује:

Комада се јава и упорно броди

ка визији краја у привид-слободи.

И даље је реч о диригованој стварности у којој превладавају стање пометье и свеколики распад али се исто тако још једном подвалачи евокативна улога поезије у свету што кидише, срља / из технике једне у јачу и бржу. Трепетни трен (раније трепет трен, трепетљике, трепке, тренуци свици, трен напрегнућа) овде је спојен са речју луч (која припада (1996).

${ }^{11}$ Круг се јавља и у наслову Тешићеве збирке Прелест севера, Круг рачански, Дунавом 
истом значењском кругу као и свици, светлост, озарење) и претварањем трошности у рефлекс давнине. Мрак је супротстављен жару што је конкретизовано у слици Жарких словеса, директно повезаних са идејом Спасења, која се сипротстављају Јединицама мрака.

И други симболи уведени одраније у Тешићев поетски свет сада се јављају у новим синтагматским спојевима и у новом контексту; њихово значење се помера а слика света изграђеног у песничком опусу Милосава Тешића постаје јаснија и богатија. Млин је у првој песми овог циклуса млин-часовник а теразије смисла раније пољуљане сада су сасвим одсутне (без тас равнотеже). Чар-нејасноћа из наслова једне од песма другог циклуса дозива чар неспознања у петом делу завршног циклуса а топонимија која премрежује читаву ову збирку (и опус Милосава Тешића) чини да Србија гране на њеним страницама. ${ }^{12}$

\section{Закључак}

Склоност Милосава Тешића да своје поетско ткање организује у шире лирске или лирско-епске целине (кругове, циклусе, поеме) проучаваоци савремене српске књижевности већ су приметили и о њој писали. Славко Гордић тако напомиње „кругове смисла које отвара и затвара Тешићево песништво" (Гордић 1998: 160) а сам аутор о својој склоности да структурно чврсто организује циклусе и читаве збирке каже:

„Да би једна песничка књига била смислено разврстана по циклусима и да би, сагласно с тим, у њима песме биле поређане по најприроднијем редоследу (као да истичу једна из друге) и добиле - како Ви (А. Ј.) кажете - 'знатна контекстуална значења', то од песника захтева композиторско умеће, то јест веома развијен осећај за складно разврставање тих песничких јединица, као и истанчано умеће у развођењу и контролисању песмотворне енергије”, и додаје:

„Када је, на пример, нека од поменутих песама у оквиру одређених песничких књига уводна, она је ту да би нешто од своје поетске носивости пребацила, пренела у наредне песме како би покренула даље певање, дала му јачи замах и упутила га у жељеном смеру. Кад је она пак изводна, то је зато што се у њој налази нешто што на значењском плану суштински сажима претходећи садржај, те јој омогућује да постане амблем дате песничке књиге, њено лирско знамење.” (Тешић 2017: 501-502)

${ }^{12} \mathrm{O}$ топонимској бројаници Милосава Тешића много је писано а сам аутор примећује да се његово стваралаштво кретало од „национално-топонимских и национално-фолклорних сфера (не губећи их ни даље потпуно из видокруга)" ка национално-историјским, религиозним, флоралним, културолошким и космичким световима, о каквим је у првом реду реч и у збирци Привид круга. Види: Тешић 2017: 494. 
Тешићеви лирски кругови на најбољи начин потврђују Дарвинову теорију по којој је повезаност лирског циклуса - тематска, сижејна, синтаксичка, стиховна итд. - условљена „циклусним понављањима... од најпростијих филолошких и стиховних до сложенијих семантичко-асоцијативних" (Стерјопулу 2003: 40). Дакле, понављање не само истих формалних одлика или основних лексичких јединица већ варирање читавог круга значења које одређене лексеме дозивају. ${ }^{13}$ И више од тога, не само да су песме унутар једнога циклуса чврсто повезане и да су циклуси складно укомпоновани у целину збирке, већ је она отворена и према ранијем Тешићевом опусу што само потврђује да је реч о песнику који је у своме стваралаштву успео да изгради сопствени поетски, у конкретном случају и митолошки, свет. Пуније значење појединих песама Милосава Тешића открива се у њиховом дослуху са циклусом и збирком у коју су уграђене али и његовим песничким делом у целини. Отуда су његове збирке изикуси цииклуса у правом значењу тог термина а његово певање израз тежње лирског песника да сачини монументалну поетско-митолошку грађевину чврсте структуре.

\section{Извори}

Тешић, Милосав. Привид круга. Београд: СКЗ, 2019.

\section{Литература}

Гордић, Славко, „Нови лирски кругови Милосава Тешића”. Милосав Тешић, песник. Ур. Александар Јовановић, Драган Хамовић. Краљево: Народна библиотека 1998. 155-162.

Јовановић, Александар, „Обред, евокација и српске хероине”, у: Милосав Тешић, Калопера Пера, Чигоја штампа, Београд, 2018. 81-104.

Микић, Радивоје. „Три песме и три песника”. Текст иза текста. Краљево: Народна библиотека „Стефан Првовенчани”, 2020. 7-20.

${ }^{13}$ Елени Стерјопулу наводи пет типова интертекстуалних лексичких понављања на којима почива организација лирског циклуса. То су: 1) лексичко понављањо у правом смислу речи („најпростија подвсрта понављања”); 2) семантичко понављање (ту убрајамо, на пример, синонимско и антонимско понављање); 3) тропијско понављање (метафора, метонимија, синегдоха); 4) тезаурусно понављање (повезивање слика из различитих текстова на основу културолошких веза); 5) асоцијативно понављање (подвста тезаурског понављања код кога повезивање слика није засновано на традиционалним културним конотацијама већ личним ауторском асоцијацијама). Сви ови типови повезивања текста, као што смо видели, могу се пратити у Тешићевој књизи Привид круга. 
Симовић, Љубомир, „Песма укрштених путева Милосав Тешић, песник. Ур. Александар Јовановић, Драган Хамовић. Краљево: Народна библиотека 1998. 25-31.

Стерјопулу, Елени Апостолос. Поетика лирсјог ичиклуса: на материјалу руске поезије с краја XIX и почетком XX века. Прев. Добрило Аранитовић. Београд: Народна књига / Алфа, 2003.

Стипчевић, Никша, „Песма укрштених путева”. Милосав Тешић, песник. Ур. Александар Јовановић, Драган Хамовић. Краљево: Народна библиотека 1998. 13-23.

Тешић, Милосав. „Певање као израз потребе за обожењем простора”. Разговор водио Александар Јовановић. Летопис Матице српске. 499. 4 (2017): 493-504.

Тешић, Милосав. Есеји и сличне радње. Београд: Завод за уџбенике и наставна средства, 2004.

Ana B. Gvozdenović

\section{LYRIC CYCLES IN THE POETRY BOOK BY MILOSAV TEŠIĆ PRIVID KRUGA}

\section{Summary}

The paper, on the example of the book Privid kruga, discusses Milosav Tešićs tendency to organize his poetry into wider lyrical or lyrical-epic wholes (circles, cycles, poems). Starting primarily from the theoretical conclusions of Elena Apostolos Sterjopoulou, the author tries to show how various intertextual lexical repetitions enable Tesic to structure the Phantom of the Circle as a cycle cycle, but also to bring the meanings of this book into close connection with his earlier work. This firmly composed poetic whole gained its full meaning by reading the poet's comments and in collusion with his earlier books.

Key words: lyric cycle, poem, commentary, cultural heritage, memory. 